\title{
Missão de Pesquisas Folclóricas: Música Tradicional do Norte e Nordeste, 1938
}

Carlos Sandroni ${ }^{1}$

Caixa com 6 CDs e 4 livretos com ilustrações e fotografias. Curadoria de Marcos Branda Lacerda. Textos de Marcos Branda Lacerda, Flávia Camargo Toni, Jorge Coli, Carlos Augusto Calil e Danilo Santos de Miranda. Seleção musical de Marcos Branda Lacerda e Rosa Maria Zamith. São Paulo: SESC São Paulo e Prefeitura da Cidade de São Paulo (Secretaria Municipal de Cultura e Centro Cultural São Paulo), 2006.

Mário de Andrade foi diretor do Departamento de Cultura do Município de São Paulo de 1936 a 1938. Como tal, enviou ao Norte e ao Nordeste do país uma equipe de pesquisadores que, de fevereiro a julho de 1938, fez gravações de música popular de tradição oral in loco em diversos pontos de Pernambuco, Paraíba, Maranhão e Pará. 0 precioso acervo reunido foi organizado e parcialmente estudado por Oneyda Alvarenga, que publicou entre 1948 e 1955 vários livros e discos relativos a ele. No início dos anos 1980, a musicóloga Flávia Toni retomou a pesquisa sobre o acervo, no que foi seguida pelo historiador e músico Álvaro Carlini e outros. Também foi nesta década que a Fundação Vitae "adotou" a coleção, possibilitando que suas condições de conservação melhorassem de maneira bastante significativa. A publicação desta coletânea, em agosto de 2006, foi justificadamente saudada - no Brasil e fora do país - como um acontecimento cultural de primeira grandeza e veio finalmente pôr ao alcance de um público amplo amostra expressiva do que foi gravado há setenta anos. (0 CD The Discoteca Collection, editado nos Estados Unidos pelo Endangered Music Project-Library of Congress em 1997, traz um fragmento muito menor do acervo e é de acesso muito mais difícil para o público brasileiro.)

A qualidade técnica das faixas é excelente, tendo em vista as circunstâncias. As gravações foram feitas com tecnologia de ponta da época: um gravador Presto Recorder que gravava diretamente em discos de acetato, os quais serviam de base para

1 Professor do Departamento de Música da Universidade Federal de Pernambuco. 
masterizacão e posterior prensagem de cópias. As condições de conservação destes discos estiveram longe das ideais até os anos 1980. Mas, desde então, os fonogramas foram guardados, digitalizados e limpos por meio dos mais avançados processos disponíveis.

0 principal critério de escolha adotado por Marcos Branda Lacerda em sua seleção foi o da inclusão de pelo menos uma faixa de cada manifestação presente no acervo. Ganhou com isso a variedade musical. A seqüência dos CDs acompanha a ordem cronológica das gravações. A coletânea começa com os cantos de carregadores de piano de Recife, um dos pontos altos do acervo. Seguem-se, entre outros: cocos, aboios, bandas de pífanos, cantoria de viola, acalantos, vários tipos de danças dramáticas, vários tipos de música religiosa, concluindo-se em Belém do Pará com a pajelança cantada por Satiro (sic) Ferreira de Barro.

A opção de incluir gravações feitas pelo Departamento de Cultura em São Paulo com uma congada de Lambari (Minas Gerais), anterior à partida da Missão, parece-me discutível. Afinal, a coletânea é apresentada como relativa à Missão de Pesquisas Folclóricas e não ao Acervo Histórico da Discoteca Oneyda Alvarenga como um todo. Este é de uma riqueza que não se resume à Missão e mereceria sem dúvida uma publicação específica, onde a congada de Lambari encontraria seu lugar.

A música registrada pela Missão não é de escuta fácil para o "ouvinte médio" (incluindo o autor desta resenha). Ainda bem. De músicas de escuta fácil, sem dúvida necessárias também, há bastante suprimento. Mas talvez o mais importante seja que sua dificuldade é de um tipo que questiona a própria noção que acabo de empregar, de "ouvinte médio". Há fortes chances de que a maneira como estas músicas seriam escutadas por pessoas a elas ligadas mais de perto seja muito diferente da minha e da do leitor ou leitora. (Tenho testemunhado isso em meu trabalho sobre a música do xangô pernambucano, ao escutar e comentar as faixas correspondentes junto com o povo do santo.) Estaria tal maneira fora da "média"? Não seria ela, talvez, relevante para a formulação de juízos propriamente críticos sobre o conteúdo da coleção?

Também por isso soa mal a seguinte afirmação no texto de Jorge Coli:

Elas [as comunidades e individualidades que produziram a música aqui registrada] não pertencem a um 'nós' brasileiro: são o outro, e impõem que se reconheça, com o respeito necessário, sua alteridade. 
A meu ver, Coli, a quem devemos, entre outros trabalhos relevantes, uma brilhante análise do "Mundo Musical" de Mário de Andrade, não pretende negar, apesar da letra do texto, a condição de brasileiras a estas pessoas, e sim afirmar que elas não resumem, mais que outros grupos definidos por outros critérios geográfico-musicais, o que é ser brasileiro, com o que, suspeito, o próprio Mário de Andrade concordaria.

Ou será que, parafraseando à inversa George Orwell, alguns grupos "são mais outros que os outros"? Justamente, a dificuldade para o tal do "ouvinte médio" é um testemunho de que a pergunta faz sentido. (Por exemplo, Marcelo Coelho, na Folha de S. Paulo de 23 de agosto de 2006, fala, a propósito destas gravações, da "impressão de um vozerio inexpugnável, estrangulado e aflito, como se alguém gritasse do fundo de um poço"). Mas esta impressão de "alteridade absoluta" é um sintoma da nossa miséria social e não algo que se relacione remotamente com o respeito a seres humanos. Bem ao contrário, ela pode nos levar a esquecer que, na origem de cada um dos fonogramas produzidos, há pessoas de carne e osso. Foi o que aconteceu no CD 1, faixas 23 ("Mandei cortar capim") e 30 ("Oh roseira"), cantadas por Senhorinha Freire Magalhães - informação pública desde janeiro de 2005 e omitida nos créditos.

Mas não é o menor dos méritos desta magnífica e longamente esperada publicação, o de nos possibilitar ouvir um pouco melhor os gritos que vêm do fundo do poço. Entender que estes gritos são também a expressão de uma musicalidade transbordante, e tão viva hoje como em 1938, é tarefa para nós, distinto público - e para as próximas gerações. 